\title{
SUPPORTING FACTORS FOR PRIMARY SCHOOL TEACHERS IN ENSURING INCLUSIVE EDUCATION FOR CHILDREN WITH AUTISM SPECTRUM DISORDERS
}

\author{
Rita Raudeliūnaitè \\ Mykolas Romeris University, Lithuania \\ Eglè Steponėnienè \\ Mykolas Romeris University, Lithuania
}

\begin{abstract}
The objective of the study presented in this article is to reveal supporting factors for primary school teachers in ensuring inclusive education for children with autism spectrum disorders (hereinafter the ASD). Qualitative research was chosen for the study. In the study, the method of a semi-structured written reflection was used. The obtained data was analysed by applying the content analysis method. Qualitative content analysis was carried out in accordance with the inductive, study data based and categories composed logic.16 primary school teachers participated in the study. The study data revealed that the school's inclusive culture and organization of inclusive education by the teacher at the classroom level had a significant importance for ensuring inclusive education for children with ASD. The school's openness to children diversity, implementation and cherishing of inclusive education values, favourable physical and psychosocial environment, ensuring support for learners, their parents, teachers and education support professionals, financial resources which allow for attracting necessary human and material resources, skilled teachers and professionals, the school's collaborating community and the school's collaboration with other institutions to ensure the quality of inclusive education were considered the key factors for the school's inclusive culture. The teacher's positive attitude to all the learners, child-oriented approach, favourable and inclusive educational and social environment created in the classroom, the teacher's close collaboration with learner's parents, other teachers and education support professionals, and continuous improvement of qualification were indicated as factors of the key importance for creation of an inclusive educational environment at the classroom level by teachers.
\end{abstract}

Keywords: children with autism spectrum disorders, inclusive education, inclusion supporting factors, primary school, teachers.

\section{Introduction}

Lithuania has committed itself to create and implement inclusive education system based on common international ethical and political education provisions which would ensure socially equitable high-quality education for all 
(Ališauskienė \& Miltenienè, 2018). Inclusive education supports and welcomes diversity among all learners. It involves changes and modifications in the educational content, approaches, structures and strategies, with a common vision that covers all children of the appropriate age range and a conviction that it is the responsibility of the regular system to educate every child (UNESCO, 2009, p. 9). When developing inclusive education, more attention needs to be given for children with special educational needs, by providing them with appropriate conditions for education in mainstream schools. Although in Lithuania legal regulation and statistical data on education of learners with special educational needs testify a formal inclusion of such learners as a predominant form of their education, yet they do not reflect the quality of their inclusive education (Ališauskas, Ališauskienè, Gerulaitis, Kaffemanienè, Melienė, \& Miltenienè, 2011).

According to Ališauskas et al. (2011), big challenges for inclusive education in many countries, including Lithuania, are related to education of children with ASD. Studies reveal that schools face challenges when creating inclusive education, particularly for children with ASD, such as school policy, lack of teachers' training and resources, lack of understanding from teachers, other students and parents (Lindsay, Proulx, Thomson, \& Scott, 2013), many teachers feel insufficient prepared to meet the multifaceted needs of children with ASD in inclusive settings (Finke, McNaughton, \& Drager, 2009, Segall \& Campbell, 2012; Majoko, 2016), etc.

Research carried out in Lithuania indicates that educational system does not provide sufficient level of attention and support for children with ASD in terms of inclusion and wellbeing in the classroom. The lack of statistical numbers about this disorder makes the evolution of the scope of this problem difficult and then organize and apply effective strategies at all levels of the public political system (Diržyte et al., 2016). A. Ališauskas et al. (2011) states that the major problems in educational process of children with ASD emerge due to their social interaction issues and specifics, lack of skilled teachers, internal and external material and physical resources, gaps in the teacher's competence development programs, low parents' involvement, and insufficient personalisation of educational programs.

Diržytė el al. state that just a minor part of teachers are prepared and know how to teach and approach children with ASD and also their families (Diržyte et al., 2016). The results of this study reveal that the teachers working in inclusive classrooms, where children with ASD study with their peers, face a lot of issues and questions concerning how to meet their personal needs related to their special educational needs, effective teaching and learning strategies how to include them into group activities and finally how to assess their skills (Diržyte et al., 2016).

A number of children diagnosed with ASD is increasing very rapidly worldwide (Lindsay et al., 2013). At the same time the need for effective methods 
and policies of dealing with those children, their families, educators and society is increasing. There are several studies and policy statements in Lithuania about inclusive environments for children with ASD. School teachers, however, face challenges in everyday practical situations in the classroom.

The aim of the study was to reveal experience of primary school teachers in ensuring inclusive education for children with ASD. The following problematic issues were addressed during the study: what helps primary school teachers to ensure inclusive education for children with ASD, what challenges are faced by teachers in ensuring inclusive education for children with ASD and what educational technologies should be applied to overcome challenges faced by teachers in ensuring inclusive education for children with ASD. The aim of this article is to reveal the supporting factors for primary school teachers in ensuring inclusive education for children with ASD.

\section{Research methodology}

Research methods. Qualitative research was chosen for the study. In the study, the method of a semi-structured written reflection was used. Written reflections included three key issues, i.e. what helps primary school teachers to ensure inclusive education for children with ASD, what challenges are faced by teachers when ensuring inclusive education for children with ASD and what educational technologies should be applied to overcome challenges faced by teachers in ensuring inclusive education for children with ASD. This article presents the study data based on one of the written reflection questions, i.e. what helps primary school teachers to ensure inclusive education for children with ASD. The obtained data was analysed by applying the content analysis method. Qualitative content analysis was carried out in accordance with inductive, databased research, where categories were logically assigned. The qualitative content analysis was reviewed for consistency, and by performing multiple readings and analysis of data, data coding, grouping codes into categories/sub-categories, and integrating categories into the context of the phenomenon analysed and description of their analysis (Creswell, 2013).

To ensure validity of the study data analysis, interview data was analysed by applying researcher triangulation, when the study data was analysed by two researchers (McMillan \& Schumacher, 2006). Prior to the data analysis, the researchers agreed concerning the principles for the analysis, i.e. the primary data analysis was performed by each researcher individually, by coding text extracts and joining them into primary categories. The researchers hereafter compared the primary categories and any mismatches between the first and the second researchers were addressed in discussions and solved through a mutual agreement between the researchers. Upon agreement between the researchers concerning 
data coding and generalization of categories, validity of the data analysis results was ensured.

Research sample. Criteria-based sample was used in the study. The informants were chosen according to the following criteria: primary school teachers who worked in general education schools and had an experience of at least 5 years in working as primary school teachers, and who had recently been working with children with ASD and had at least one year experience in working with children with ASD in mainstream classrooms at general education schools. The study was conducted in May 2019. 16 educators participated in the study. The teachers reflected their experience in the written-form based on the three questions of reflection mentioned. The reflection took up to one week.

Research ethics. The informed consent for the participation in the research was taken from every single participant. Researchers assumed an obligation not to disclose any information related to the school and the informant. The principles of anonymity, volunteerism and benevolence were followed. The educators were acquainted with the aim of the research, the questions of written reflection, and the importance of argumentated reflection on their experience. In order to ensure confidentiality for research participants, their names were coded by using a letter I and number (I1, I2 etc.).

\section{Analysis of research results}

The primary school teachers who participated in the research acknowledged that education of children with special educational needs emerging due to disabilities, including ASD, in the educational system together with their peers had a positive impact on the children and the school's entire community. According to A.Ch. Dybvik (2004), when inclusion is appropriate and truly premised on inclusive pedagogical practices, children with disabilities and their peers can benefit from being together (as cited in Goodal, 2015, p. 309). If children are not having their potential realised within a school permeated by an inclusive ethos, with inclusion-orientated practitioners, then ASD-specific provision could be justified (Goodal, 2015, p. 309).

The study data revealed that the school's inclusive culture and organization of inclusive education by the teacher at the class level had a significant importance for ensuring inclusive education for children with ASD (Fig. 1). 


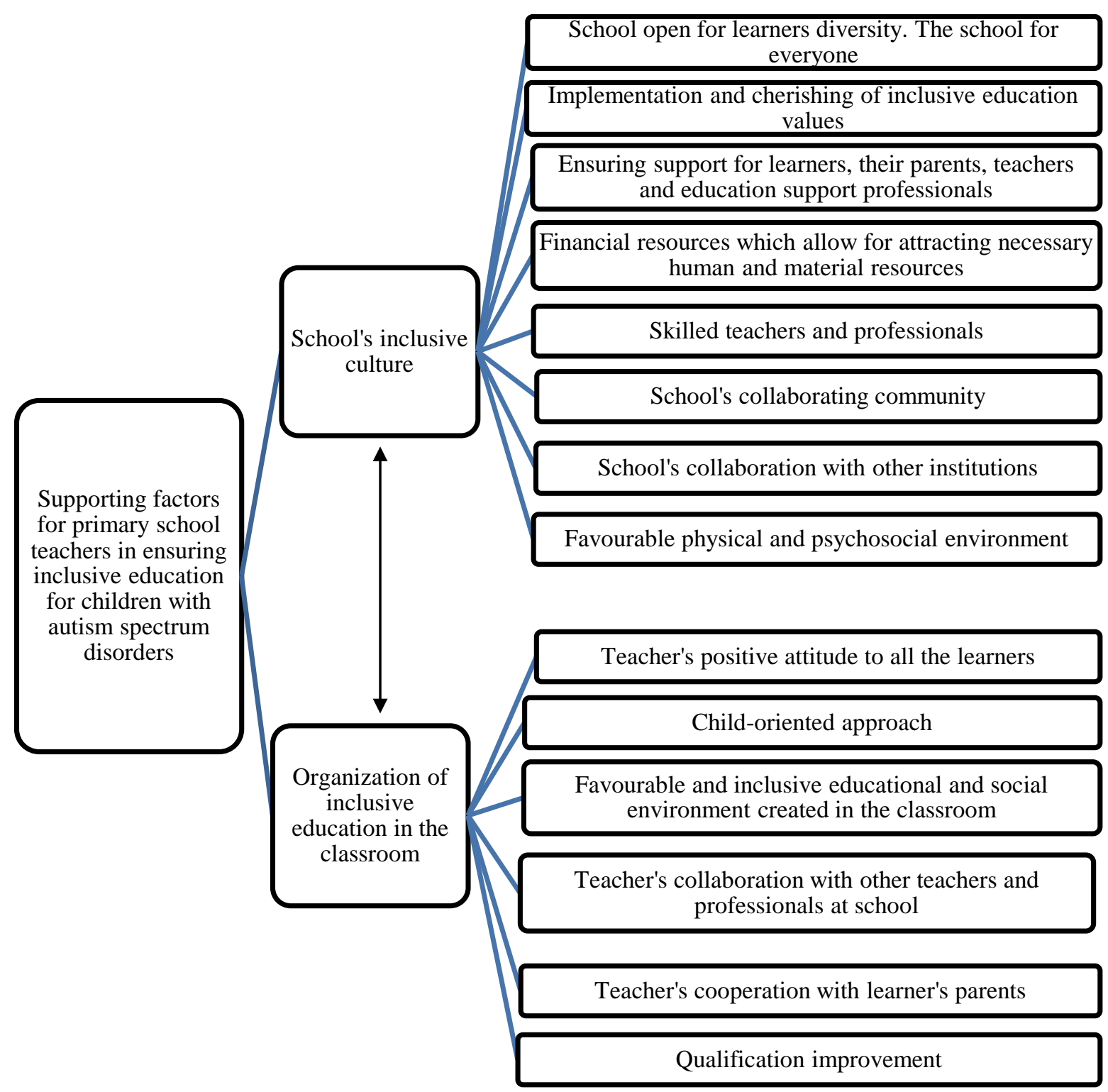

Figure 1 Supporting factors for primary school teachers in ensuring inclusive education for children with ASD

The study reveals that the school's inclusive culture is related to the school's openness to children diversity and creation of the school for all. The participants of this research claimed that "declaration of inclusive education in documents is not enough, it should be implemented and visible in real life of the school as well" (I1). Informants stressed that „every child should be welcomed at school” (I16) and "every child should be cared for and feel valued" (I5). Noteworthy, the school's community would face fewer challenges, if it was positively disposed and ready to accept a child with a disability. According to informants, "this is not 
a mechanical shifting of a child with ASD to a mainstream school” (I I16), 'it is important for the school to which the child with ASD comes to be ready and have a will to accept the child' (I13). Informants specified that „the administration plays an important role in the formation of the school's inclusive policy and culture" (I4), "when administration considers inclusive education a priority, the school's community is enabled to create inclusive educational environment" (I13). Based on the study participants' thoughts, "collective implementation of inclusive education by putting common efforts will reduce a contradiction between declaration of inclusive education and its actual implementation in schools" (I5). Efficient inclusive education is possible when the school's management and the school's entire community evidently consider inclusive education as a value and when a favourable environment for efficient education of children with different needs is created in the school (European Agency for Special Needs and Inclusive Education, 2007).

Establishing of the inclusive education values is a significant part of the school's inclusive culture. Informants claimed that "it is important for both: managers of the school and every teacher and educational support professional to perceive the meaning of inclusive education values and follow the values in their work" (I10). For this purpose, it is important, according to the informants, "to accept all the learners the way they are" (I3), "some teachers and specialists need to change their attitudes and decline labelling of children, which devalues possibilities of children with special educational needs in particular, as it obstructs any collaboration and creation of inclusive environment" (I11), "to strengthen the understanding that a child is first of all a child, irrespective of his behaviour, ability to study, etc." (I2), "to consider individual abilities of every child, not to forget his needs, by trying to respond to the needs and have necessary conditions for their satisfaction" (I7), "provide all children with possibilities to be and act together" (I12). The facts mentioned above indicate that inclusive education can be achieved only when thinking about every learner in the school. Respect to the diversity of every learner, education that mets individual needs and interests, encouraging of the learner's powers and abilities, enabling of all learners to feel part of their class and school community by being and working together, and feeling valued and useful are considered important values of inclusive education. The school should see diversity as a strength and a stimulus for further learning (European Agency for Special Needs and Inclusive Education, 2011, p. 14).

The study indicates that ensuring of support for learners, their parents, teachers and education support professionals is considered an important part of the school's inclusive culture. According to the participants of the study, in order to ensure inclusive education for children with ASD, it is important that "the school would not lack education support professionals and their assistance to the child, teachers and parents" (I9), "have enabling resources which contribute to 
receiving support inside the school or by employing assistance from the outside" (I4). An informant claimed that "when teachers, education support professionals and parents get more support, consulting and training from skilled professionals, they will be able to better solve problems faced in the child's education sphere" (I10). As J. Anglim, P. Prendeville \& W. Kinsella noted, teachers' sense of efficacy in meeting the needs of pupils with ASD was related to the amount and type of support that they perceived themselves to be receiving at the time (Anglim et al., 2018).

In addition, the study participants stressed the importance of financial resources and ability to manage such resources to ensure a possibility to attract necessary human and material resources which enable ensuring of inclusive education. Report on the monitoring of the social integration of persons with disabilities and the United Nations Convention on the Rights of Persons with Disabilities and its Optional Protocol 2017 note that Lithuania needs to improve individualized support and assistance provided to the persons with disabilities and their family members in educational institutions, increase a number of teachers, their assistants, speech therapists and special educators working with the children with disabilities in educational institutions, and grant possibilities for availability of necessary professional's support (Report, 2018).

The study reveals that the qualification of teachers and other professionals and possibilities for continuous training are important factors for the school's inclusive culture. According to informants, "one of the key steps when creating an inclusive school is qualification of its teachers and professionals and its continuous improvement in ensuring inclusive education" (I10), therefore "priorities for and types of continuous training need to be discussed at the school, by considering the emerging needs for continuous training and providing attention to inclusive education of children with special educational needs in mainstream classrooms, rather than focussing only on development of subject competencies" (I3). An inclusive educational approach is based on teachers' beliefs that they are capable of teaching a diverse range of children through creatively adapting practice to support the learning of all (Florian, 2014). Any successful intervention will be highly dependent upon the skills of school staff employed and on providing them with adequate resources (McAllister \& Hadjri, 2013). The European Agency for Special Needs and Inclusive Education in its report Key principles for Promoting Quality for Inclusive Education - Recommendation for Practice stresses that all teachers should develop the skills necessary for effective education of all learners by considering each learner' needs. In their initial and continuing education, teachers should be equipped with the skills, knowledge and understanding that will give them the confidence to deal effectively with a range of learner needs (European Agency for Special Needs and Inclusive Education, 2011, p. 15). 
The study shows that the school's collaborating community is a significant factor for the school's inclusive culture. Collaboration and team work are considered one of the essential principles of inclusive education. The participants of this study put a particular stress on the importance of collaboration when adjusting and implementing education programmes and individual educational plans. The study participants specified that collaboration enables a better "recognizing of and responding to the child's individual needs" (I1), "setting of clear aims and responsibilities and obligations for everyone" (I3). When working in a team and collaborating, emerging problems can be seen in a wider context. According to an informant, "collaboration helps to broaden the field of seeing a problem, discuss and better see what probably needs to be changed at the school or at home to improve the child's learning situation" (I12). Wider use of collaborative and reflective practice may allow greater opportunities for teachers to share examples of good practice and build confidence in their ability to differentiate the curriculum to meet the needs of all pupils with ASD (Anglim et al., 2018, p. 86).

The school's collaboration with other institutions also serves as an important factor for the school's inclusive culture. The research indicates that collaboration with other institutions is urgent for developing skills of teachers and education support professionals, providing support for children with ASD and their families, sharing of good practice in adjusting the environment, and consulting and receiving support in case of emergencies. J. Anglim et al. suggest that a lack of effective collaboration between professionals and a lack of multi-agency sharing of information are barriers to inclusion (Anglim et al., 2018).

The study reveals that favourable physical and psychosocial environment at school is a significant factor for the school's inclusive culture. Noteworthy, children with ASD are more sensitive to their environment. K. McAllister \& $\mathrm{K}$. Hadjri noted that being sensory sensitive and unable to integrate fully and communicate with others means that the person with ASD can find the world a disorientating and even frightening place (McAllister \& Hadjri, 2013, p. 58). Therefore, according to an informant, "one of the key tasks is to adjust the school's environment to satisfy the child's needs. If we fail to satisfy the child's needs, we cannot reveal his/her potential” (I4). On the one hand, the participants of this research stressed the importance of adjusting the environment at the school and classrooms and proper teaching aids. According to the informants, "the school's physical environment both inside and outside should be accessible and safe for children with ASD" (I10), "from the place of the seat to lighting in the classroom, from the noise level to adjusting of teaching tools - all of these are determining factors when creating suitable physical environment" (I4), "the areas adjusted for children relaxation are needed as well" (I12), and in addition, "it is important to create physical areas at school, which would ensure good conditions 
for keeping learners busy and satisfaction of their needs not only during classes, but also during the time off classes” (I10). Autism awareness is a combination of both: the human component and the built environment. According R. Khare (2010), just as a well-designed environment can be supportive, an ill-conceived environment can be harmful to a child's education (as cited in McAllister \& Hadjri, 2013, p. 58).

In addition, the study participants attached great importance to creation of favourable psychosocial environment. According to teachers, "physical presence of a child with ASD in the mainstream classroom is not enough, it is also important for the child to feel good in the classroom and be involved in activity together with other children, to have good interpersonal relationships with the entire classroom community and certainly a friendly atmosphere in the whole school" (I14), "all the children should have the school and the classroom where they would feel good" (I1). The above indicates that the study participants put a particular stress on the importance of learners' well-being and community when creating a favourable psychosocial environment. According to K. McAllister \& $\mathrm{K}$. Hadjri, to a child, a school is many things; not just a place of learning but also a place of new experiences, a test bed to develop social skills and a supportive environment in which to develop and find themselves. In all aspects it should be an environment in which the child feels comfortable (McAllister \& Hadjri, 2013, p. 63-64).

The teacher's activity in the classroom is also of great significance in an inclusive school. What happens in the classroom makes a big impact on all the learners being there. The research established that teachers acknowledged their essential role in creating inclusive educational environment in the classroom. The study reveals that when organizing inclusive education at the classroom level a great importance lies with the teacher's "positive attitude to the child and the teacher himself/herself and believing that you can change something” (I2), therefore it is important "to focus on the child's resources, develop his abilities by believing in his/her achievements" (I9). According to an informant, "positivity encourages a will to have collaboration and initiative, reduces stress, and creates a feeling of confidence and openness for collaboration with the child" (I11). The European Agency for Special Needs and Inclusive Education in its publication "Five Key Messages for Inclusive Education” notes that inclusion largely depends on teachers' attitudes towards pupils with special needs, on their view on differences in classrooms and their willingness to deal with those differences effectively. Generally, the attitude of teachers has been put forward as a decisive factor in making schools more inclusive (European Agency for Special Needs and Inclusive Education, 2014).

The teacher's positive attitude to learners is closely related to a childoriented approach directed to recognition and acknowledgement of every child's 
individuality and exceptionality. Education cannot be individualized without a new attitude of educators towards children individuality and acknowledgement of manifestation of individuality in educational process as a value (Juodaityte, 2014). The study participants stressed that "the attitude to the child should be based on the child's potential abilities, by highlighting his strengths" (I3), “a child has an individuality and we work with the child, develop his abilities and do not try to make him just like everybody is" (I9). The study participants indicated that "the child's needs must be satisfied, if we fail to satisfy the child's needs, we cannot reveal his/her potential" (I4). For this purpose, according to informants, "it is important that the child receives any necessary support provided by responding to his/her personal needs". The study results revealed that in the context of the childoriented approach, particular importance lies with encouraging every child's initiative, the child's active involvement in activity and empowering the child to succeed. According to the participants of this research it is important "to find an individual access to the children" (I8), "to provide the child with a possibility to express himself, his potential and reveal himself" (I3), "to enjoy the child's achievements, even minor ones, together with parents, other learners and teachers, rather than underestimate the child" (I11).

The results of this study show that when organizing inclusive education, creation of favourable and inclusive learning and social environment by teachers is important. Learning is not only individual, but also a social process. Therefore, it is important to include the areas of personal and social skills development of learners into the educational process, and enable learners to collaborate and create positive reciprocal relations. The participants of this study stressed that when creating favourable and inclusive learning and social environment in the classroom, the teacher primarily has to create positive interactions with every child. The above is illustrated by the following statements by informants: "I would say that the teacher's ability to enter into and develop positive relations with every child is a foundation for creation of favourable microclimate in the classroom" (I15), "one should primarily start from himself/herself and serve as a role model for children concerning what respect for others and proper relations are" (I1), "a trust in the strengths of the child with ASD and his/her progress need to be demonstrated for the entire class, positive thinking is needed to help the child to overcome challenges, the child's strengths must be recognized" (I14), "it is important for children to succeed, they should receive more public praises and encouragement, thus the child will become more self-confident and other people will see his progress" (I10), but "if the educator himself distinguishes and underestimates abilities of the child with any kind of disorder, other learners will follow this example as well" (I8). The above indicates that a positive relationship with learners, created by the teacher, serves as an example for children on how respectful and proper mutual relationship should be created. In addition, 
according to O. Monkevičienè, reciprocal relationships between children with special educational needs and other learners in the classroom will develop successfully, if the barriers obstructing their development are eliminated. One of the educational strategies in this field is the teacher's trust in the learner strengths' transformability and showing of this trust in front of the entire classroom (Monkevičienè, 2017). According to the author, when seeing a positive and dynamic change of their powers, learners with special educational needs naturally accept their differences and thus their dignity increases; when seeing a positive and dynamic change of the powers of children with special educational needs, other learners in the classroom naturally accept their differences and respect them (Monkevičienè, 2017).

The study revealed that when creating inclusive learning and social environment in the classroom, social interactions among all the learners in the classroom should be encouraged and conditions for learning through collaboration should be granted. The study participants indicated that it was very important "to provide children with ASD with possibilities to participate in common activity with their peers during classes and during extra curriculum activities" (I2), "to organize as many common activities and group occupations as possible, without isolating children with ASD” (I10). Informants stressed the need "to help other children to have a better knowledge of special needs of the child with ASD" (I16), "to encourage respect for diversity of the peers" (I3). S.G. Soulis, A. Georgiou, K. Dimoula, \& D. Rapti research shows that children in the classroom have a negative attitude towards their peers with special educational needs, when they are unsure what these learners are capable of, what they are incapable of and why (Soulis et al., 2016). The study participants claimed that "both children with ASD and other children need to develop social skills, because when lacking those skills children face challenges in communicating and collaborating with others" (I14). Therefore, according to informants, "common activities are useful for developing social skills of children” (I8), "encouraging of social interactions helps children with ASD to have more social relationships with other children, which are important for development of social skills” (I15). O. Monkevičienè claims that when having a lot of social contacts, the child with special educational needs feels being a member of the classroom, develops necessary social skills and feels well in the classroom (Monkevičienė, 2017).

The teacher's close collaboration with the child's parents, other teachers and education support professionals is specified by the study participants as an important factor for ensuring effective practice of inclusion. The study participants indicated that "it is important for teachers to receive practical support and assistance from colleagues" (I2), "it is good when regular meetings are organized where we can exchange our experience, raise the problems we face and share insights for their solution" (I16), "sharing of professional experience 
contributes to our competence improvement” (I5), “collaboration encourages professional development, since it enables exchange of experience, learning from others and enriches us with practical examples of inclusion” (I12). The teachers who participated in the research acknowledge the importance of "listening to parents, taking their opinion into consideration, making decisions through collaboration, related to the child's education and provision of support for the child" (I8), "strengthening of collaboration with the parents in searching for new forms of collaboration, so that parents become a part of the institution's life and get better involved in the child's educational process and its continuation at home" (I2). In addition, according to informants, the parents should "be encouraged to be more actively involved in the child's educational environment and communicate more often not only with teachers and other professionals, but also with the child's classmates" (I10), "participate in the child's educational process: in its planning, implementation, and in discussions concerning the child's learning” (I6). Inclusive education can be implemented only through listening to expectations and needs of all the education stakeholders, by creating partner relationship based on collaboration.

The teachers who participated in the research indicated that teachers' professional preparation and development facilitate the inclusion of children with ASD in mainstream classrooms. Informants noted the importance of organizing the training oriented to practical application and of particular methodologies dedicated to approach children with ASD. The study participants indicated that to ensure inclusive education for children with ASD, they notably needed the knowledge which would help them to identify the individual educational needs of these children, as well as to select and apply appropriate ways for solution of problem behaviour, effective educational strategies and tools for developing social skills, and effective methods for information transmission, which encourage cognitive processes. Similar trends have been revealed in other studies (Sansosti \& Sansosti, 2012; Corkum, Bryson, Smith, Giffin, Hume, \& Power, 2014; Majoko, 2016), which noted that teachers need professional development in order to be informed and knowledgeable about ASD and about individualisation strategies for children with ASD and techniques for improving the behavioural, social, and academic outcomes of students with ASD in mainstream classrooms.

\section{Conclusions}

The study data revealed that the school's inclusive culture and organization of inclusive education by the teacher at the class level have a significant importance for ensuring inclusive education for children with ASD in in a mainstream schools. 
The study indicates that among the important factors for the school's inclusive culture is creation of open school for everyone, by developing favourable environment for learners with different needs to stay together and receive effective education, with the aim to eliminate any obstacles for learning and participation and avoid any exclusion, where every member of the community would feel accepted and important. The school's inclusive culture is related to establishing of inclusive education values in the school's community, favourable physical and psychosocial environment created, and a prevailing atmosphere of collaboration, support and assistance for each other. Qualification of teachers and other professionals and its continuous improvement, as well as the school's collaboration with other institutions to ensure the quality of inclusive education are important factors for the school's inclusive culture. In addition, great importance is attached to financial resources and ability to manage such resources to ensure a possibility to attract necessary human and material resources which enable ensuring of inclusive education.

When developing inclusive educational environment at the classroom level by teachers, significance is attached to the teacher's positive attitude to all children and a child-oriented approach directed to recognition and acknowledgement of every child's individuality and exceptionality, with the aim to respond to every child's needs and interests, by encouraging his/her powers and abilities and by cherishing high expectations concerning every child. In addition, favourable and inclusive learning and social environment in the classroom created by the teacher is important. In this context, the teacher should create positive relationship between the teacher and learners, and among the learners themselves, by showing a trust in the powers of every child and his progress for the entire class, by assisting the child in overcoming challenges, noticing his/her strengths and empowering every child to succeed. Moreover, making conditions for learner education through collaboration is essential. The participants of this research indicate the teacher's close collaboration with the families, other teachers and education support professionals as important factors for ensuring effective practice of inclusion. The teacher's personal continuous professional development is also very important. The study reveals that teachers attach importance to epistemic information (knowledge on ASD specifics) and notably instrumental information (knowledge on how to work with children with ASD and create inclusive environment) when ensuring inclusive education for children with ASD.

\section{References}

Ališauskas, A., Ališauskienė, S. Gerulaitis, D., Kaffemanienè, Melienė, R., \& Miltenienė, L. (2011). Specialiuju ugdymo(si) poreikiu tenkinimas: Lietuvos patirtis užsienio šaliu kontekste. Šiauliai: VšI Šiaulių universiteto leidykla. 
Ališauskienė, S., \& Miltenienè, L. (2018). Inkliuzinis ar įtraukusis ugdymas: socialinių konstruktų interpretacijos švietimo kaitos kontekste. Specialusis ugdymas, 1(38), 11-43.

Anglim, J., Prendeville, P., \& Kinsella, W. (2018). The self-efficacy of primary teachers in supporting the inclusion of children with autism spectrum disorder. Educational Psychology in Practice, 34(1), 73-88.

McAllister, K., \& Hadjri, K. (2013). Inclusion and the special educational needs (SEN) resource base in mainstream schools: physical factors to maximise effectiveness. Support for Learning, 28(2), 57-65.

Corkum, P., Bryson, S.E., Smith, I.M., Giffin, C., Hume, K., \& Power, A. (2014). Professional development needs for educators working with children with Autism Spectrum Disorders in inclusive school snvironments. Exceptionality Education International, 24, 33-47.

Creswell, J.W. (2009). Research design: Qualitative, Quantitative and mixed methods approaches. London: Sage.

Diržytė, A., Mikulènaitė, L., \& Kalvaitis, L. (2016). Autizmo sutrikimu turinčiu vaiku situacija ir įtraukties $i$ švietimo sistema galimybès. Vilnius: VšI „Pažangos projektai““.

European Agency for Special Needs and Inclusive Education. (2007). Assessment in Inclusive Settings: Key Issues for Policy and Practice. Retrieved from https://www.europeanagency.org/sites/default/files/assessment-in-inclusive-settings-key-issues-for-policyand-practice_Assessment-EN.pdf

European Agency for Special Needs and Inclusive Education. (2011). Key Principles for Promoting Quality for Inclusive Education - Recommendation for Practice. Retrieved from https:/www.european-agency.org/sites/default/files/key-principles-for-promotingquality-in-inclusive-education-recommendations-for-practice_keyprinciples-rec-LT.pdf

European Agency for Special Needs and Inclusive Education. (2014). Five Key Messages for Inclusive Education. Retrieved from https://www.european-agency.org/ English/ publications

Finke, E.H., McNaughton, D.B., \& Drager, K.D.R. (2009). All children can and should have the opportunity to learn: General education teachers' perspectives on including children with autism spectrum disorder who require ACC. Argumentative and Alternative Communication, 25, 110-122.

Florian, L. (2014). Reimagining special education: Why new approaches are needed. In L. Florian (Ed.), The SAGE handbook of special education (pp. 9-23). London: Sage.

Goodal, C. (2015). How do we create ASD-friendly schools? A dilemma of placement. Support for Learning, 30(4), 305-326.

Juodaitytè, A. (2014). Vaikų individualizuoto ugdymo pedagoginės rekonstrukcijos: diskursai ir metakontekstai. Tiltai, 66(1), 237-248.

Lindsay, S., Proulx, M., Thomson, N., \& Scott, H. (2013). Educators' challenges of including children with autism spectrum disorder in mainstream classrooms. International Journal of Disability, Development and Education, 60(4), 347-362.

Majoko, T. (2016). Inclusion of Children with Autism Spectrum Disorders: Listening and Hearing to Voices from the GrassFroots. Journal of Autism and Developmental Disorders, 46, 1429-1440.

Monkevičienė, O. (2017). I mokinių pozityvių tarpusavio santykių plètotę orientuotos pedagoginès strategijos įtraukiajame ugdyme. Pedagogika, 127(3), 87-103.

McAllister, K., \& Hadjri, K. (2013). Inclusion and the special educational needs (SEN) resource base in mainstream schools: physical factors to maximise effectiveness. Support for Learning, 28(2), 58-65. 
SOCIETY. INTEGRATION. EDUCATION

Proceedings of the International Scientific Conference. Volume IV, May $22^{\text {th }}-23^{\text {th }}, 2020.84-98$

McMillan, H., \& Schumacher, S. (2006). Research in education: Evidence-Based Inquiry. New York: Pearson Education.

Neigaliuju socialinès integracijos veiklos rezultaty ir Jungtiniu Tautu neigaliuju teisiu konvencijos ir jos fakultatyvaus protokolo 2017 m. stebèsenos ataskaita. (2018). Retrieved from: http://www.ndt.lt/wp-content/uploads/Konvencijos_stebesenos_ ataskaita_GALUTINE-word.pdf

Sansosti, J.M., \& Sansoti, F.J. (2012). Inclusion for students with high-functioning autism spectrum disorders: definitions and decision making. Psychology in the Schools, 49(10), 917-931.

Segall, M.J., \& Campbell, J.M. (2012). Factors relating to education professionals' classroom practices for the inclusion of students with autism spectrum disorders. Research in Autism Spectrum Disorders, 6, 1156-1167.

Soulis, S.G., Georgiou, A., Dimoula, K., \& Rapti, D. (2016). Surveying inclusion in Greece: empirical research in 2683 primary school students. International Journal of Inclusive Education, 20(7), 770-783.

UNESCO. (2015). Framework for Action Education 2030: Towards inclusive and equitable quality education and lifelong learning for all. World Education Forum. 